\title{
Foreword: EU energy policy and the strategic value of renewable energy promotion
}

\section{Mischa Bechberger}

As demonstrated in the Copenhagen climate summit, the approach of a global climate regime based on strong and binding greenhouse gas (GHG) reduction targets for industrialized countries, as well as on growing reduction commitments for emerging and developing countries, has largely failed (Scheer, 2010). Besides, the most prominent climate mitigation option of the conventional power industry, nuclear energy, will probably lose government support after the 2011 Fukushima power plant nuclear disaster in Japan, as demonstrated by the decision of the German Government to phase out nuclear until 2021/2022 (Greenpeace, 2011). Therefore, the most efficient, effective and least costly solution for rapidly reducing global GHG emissions is clearly through a very rapid expansion of renewable energy sources (RES) in the global and European energy mix. This would also help to decrease significantly Europe's growing fossil fuel energy import dependency, which in 2008 had already reached 54.8\% for the EU-27 (Eurostat, 2011, p. 26).

The strategic importance of RES for the EU energy policy has been demonstrated lately through the political upheavals in the Arab World, involving some of the main oil and/or gas suppliers of Europe (Eurostat, 2011, pp. 40ff.). The EU RES promotion policy should therefore be seen as the only strategic option for rapidly reducing European GHG emissions and the aforementioned energy import dependency. Bearing in mind also that, owing to the 2011 political upheavals in North Africa and the Middle East, June 2011 oil prices - at around US\$115 per barrel - have already reached the second-highest levels since the historical peak of summer 2008 (Manager Magazine, 2011). In this sense, RES can avoid a lot of GHG emission rights and fossil fuel import costs, which would be much higher in total than the financial support required for a massive deployment of RES.

At the same time, RES could create a lot of new jobs, a very important factor in times of global economic downturn. The best way to do this, as shown in various recent studies (EREC, 2010; ECF, 2010; Jacobson and 
Delucchi, 2009; EREC and Greenpeace, 2010), would be through stable (macro-) legal frameworks and binding mid- and long-term targets, combined with strong energy efficiency measures. Whereas there are still many doubts as to when and what extent a new global climate regime might be established (Scheer, 2010), RES is growing at a fast pace, both at a European and a global level, thereby constituting one of the most important means of GHG reductions in recent years.

According to the European Photovoltaic Industry Association (EPIA), in 2010 the growth of the photovoltaic (PV) markets worldwide reached a newly installed capacity of 16.7 gigawatts $(\mathrm{GW})$, experiencing a $132 \%$ growth compared with 2009. The total installed global PV capacity has therefore reached 39.6 GW. In Europe in 2010, PV became for the first time the RES electricity (RES-E) technology with the largest amount of newly installed generation capacity, ahead of wind energy and outperformed only by gas-fired plants (EWEA, 2011, p. 6). This also translated into investments of over $€ 50$ billion in 2010. PV technology has reduced its unit costs to roughly a third of what they were five years ago, thanks to continuous technological progress, productive efficiency and its wide implementation. The trend of decreasing unit costs will also continue into the future. Thus, PV technology has all the potential to meet a double-digit percentage of the electricity supply needs in every major region of the world.

Looking ahead, a share of over 20 percent of world electricity demand in 2050 appears feasible. Such amounts of PV would avoid a cumulative total of 65 billion tonnes of $\mathrm{CO}_{2}$ emissions between 2020 and 2050 (EPIA and Greenpeace, 2011, pp. 3ff.). As for wind, according to the Global Wind Energy Council (GWEC), despite being hit by the financial crisis of 2008-09, the global wind market nevertheless grew by 22.5 percent in 2010 , with an investment growth of 31 percent, reaching a record level of US\$ 96 billion and an overall installed global wind capacity of 194.4 GW. By 2015, annual market additions are expected to reach $60.5 \mathrm{GW}$, up from $35.8 \mathrm{GW}$ in 2010 . This will lead to a doubling of the overall installed worldwide wind capacity to nearly $450 \mathrm{GW}$ by 2015 (GWEC, 2011, pp. 10ff.). Regarding global investments in RES, the Renewable Energy Policy Network for the 21st Century (REN21) showed in its 2010 Global Status Report that investment in renewable energy power capacity (excluding large hydro) in 2009 was comparable to that in fossil-fuel generation, with both at around $\$ 100$ billion. If the estimated $\$ 39$ billion of investment in large hydro is included, then total investment in RES exceeded that in fossil-fuel generation for the second successive year. According to REN21, in 2012, the world as a whole will add more capacity to the electricity supply from renewable than non-renewable sources (REN21, 2010).

At the European level, the original capacity targets for RES-E for 2010 (established for the first time in 1997 through the RES White Paper) have been 
widely exceeded. In the case of wind, at the end of 2010, more than $84 \mathrm{GW}$ had been installed, instead of the forecasted $40 \mathrm{GW}$. Regarding PV, the $3 \mathrm{GW}$ target has been exceeded more than nine times over, reaching an installed capacity above $27 \mathrm{GW}$ (EREC, 2011, p. 11). How has this impressive development been possible?

At a European level, the focus is mainly on Germany's successful PV development, reaching more than $17 \mathrm{GW}$ of installed capacity at the end of 2010, representing 43 per cent of the cumulated world PV market. This has been achieved thanks to an exemplary feed-in tariff (FIT) law since 2000, which always guaranteed a high level of planning and investment security and allowed small private investors to invest in clean, smart and locally distributed generation facilities. Germany is also still leading the European ranking in wind energy, with $27.2 \mathrm{GW}$ of installed capacity at the end of 2010 (GWEC, 2011, p. 11).

And it is not only Germany showing an impressive growth of RES-E capacity, but also other EU member states, like Italy (at least $2.3 \mathrm{GW}$ ), the Czech Republic $(1.4 \mathrm{GW})$ and France $(0.7 \mathrm{GW})$ in the case of PV capacity newly installed in 2010, or Spain $(1.5 \mathrm{GW})$, France $(1.1 \mathrm{GW})$, the UK $(1 \mathrm{GW})$ and Italy $(0.9 \mathrm{GW})$ in newly installed wind capacity in 2010 (GWEC, 2011, p. 11). On the one hand, this is based on strong national RES-E support schemes, while on the other hand it is basically thanks to an ambitious and forward-looking EU RES policy, which began as early as 1997 through the first White Book on RES, followed by two important Directives to promote RES-E in 2001 and biofuels in 2003 (including indicative European and national targets for 2010) and, lately, the new EU RES framework Directive of 2009, which for the first time comprised all RES subsectors (including RES heating and cooling) and relatively ambitious binding targets for RES at EU and country levels (Bechberger, 2009, pp. 536ff.). To ensure these targets are fulfilled, the RES Directive also included the obligation for member states to draft and then submit so-called national renewable energy action plans (NREAP) to the European Commission, following general guidelines and using a template in which they had to forecast the overall RES share of final energy consumption (at least meeting the minimum overall RES target fixed within the RES Directive for each member state and the various subsector and single technology targets) and, most importantly, describing the measures already established or still necessary to adopt in order to meet the different RES targets by 2020. Interestingly, while the member states had to submit their NREAPs by the end of June 2010, it was not until the end of 2010 that all 27 NREAPs were delivered.

As a first analysis of all the NREAPs, the following main results can be highlighted: altogether, the member states expect to exceed the minimum target of 20 percent of RES in final energy consumption by 0.7 percent in 2020. Regarding subsector targets, the NREAPs foresee achieving a share of 
RES to meet 34.3 percent of electricity demand, 21.3 percent of heating and cooling demand and 11.3 percent of transport consumption (ECN, 2011, pp. 6ff.). According to these numbers, it looks at first glance like the ambitious EU RES policy has been reaffirmed by a majority of the member states.

The EU REPAP 2020 project (www.repap2020.eu), in its first phase, provided strong scientific input to the authors of the NREAPs by preparing the national RES industry road maps. In a second phase, the project is both closely following the transposition of the RES Directive into national legislation and also evaluating the national NREAPs. A recently published analysis of the NREAPs states that substantial optimization potential exists for all five categories (administrative procedures and spatial planning, infrastructure development and electricity network operation as well as support measure for RES-E, heating and cooling and within the transport sector). The strongest deficits exist in the field of administrative procedures and spatial planning followed by the category support measures for RES heating and cooling. The highest optimization potentials exist in these two areas. Even the section of support measures in the electricity sector receives only a neutral evaluation on average, showing room for improvement in many EU member states (Ragwitz et al., 2011, p. 2). Therefore the same project showed that even higher shares of RES in the EU energy mix could be reached by 2020.

The European RES industry (based on the NREAPs' energy demand scenarios) shows that 24.4 percent of RES in final energy demand can be achieved, provided always that appropriate policies are in place, such as: clear, stable (never retroactive!), technology-specific promotion schemes for RES-E technologies, new incentives for combined heat and power plants and district heating and cooling, priority access/dispatch of RES in all member states, and improved storage capacity planning; the streamlining of permit procedures (mainly for small(er) RES installations, including one-stop-shop approaches), re-established access to equity finance for small and medium enterprises, as well as small private-investor and project bonus and national RES funds, to be fed by the proceeds of auctions under the European Emissions Trading Scheme (EU ETS) from 2013 onwards; strong infrastructure investments based on the new EC infrastructure package of late 2010, including several priority projects (such as new interconnection lines); and last but not least, and of utmost importance, the adoption of ambitious, binding and long-term energy-efficiency targets (which, as a first step might be established within the recasting of the Energy Service Directive), to mention just a few of the policy recommendations of the Repap2020 project (Fouquet, 2011). Moreover, the NREAPs anticipate that the share of RES will meet 34.3 percent of electricity demand, 21.3 percent of heating and cooling and 11.3 percent of transport consumption, while the RES industry (based on the NREAPs' energy demand scenarios and supposing the introduction of the aforementioned measures) 
suggests that 42.3 percent of electricity consumption, 23.5 percent of heating and cooling and 12.2 percent of transport consumption is attainable by 2020 (EREC, 2011, p. 6).

Although these estimates for 2020 might already look ambitious and would require the deployment of at least a larger part of said measures, they could only signify a first, yet very important, intermediate step towards a complete ecological transformation of the European and global energy mix based entirely on RES by 2050 . To make such a transformation come true, what would be needed besides the aforementioned supportive measures, on the one hand, are a fast and complete transposition of the RES Directive and a close and effective monitoring by the European Commission, including infringement procedures in case of non-compliance with the main provisions and targets of the Directive. On the other hand, what is also needed is an adoption of 2030 (and at a later stage also 2040) EU targets for RES as early as possible, in order to give these completely carbon-free energy sources the strategic importance they deserve in the future EU energy mix.

Such a complete switch to RES at EU level, by 2050 at the latest, not only is already possible with the latest RES technologies available today but also would lead to huge overall macroeconomic benefits, as was shown in 2010 through the $100 \%$ RES scenario for 2050 by EREC called 'Re-Thinking 2050'. In this report, EREC demonstrated that, even without an aggressive energy efficiency policy, the EU could achieve an effective 96 percent share of renewable energy in final energy consumption by 2050 (the remaining 4 percent stems from the assumption of remaining fossil fuel uses in aviation and inland navigation by 2050). Based on this almost 100 percent RES share by 2050 , the avoided $\mathrm{CO}_{2}$ costs in 2050 alone (assuming a $\mathrm{CO}_{2}$ price of $€ 41$ per tonne in $2020, € 45 / \mathrm{t}$ in 2030 and $€ 100 / \mathrm{t}$ by 2050) would exceed the cumulative investment of $€ 2800$ billion necessary to reach $100 \%$ RES share by 2050 by $€ 1000$ billion. When taking into account the fossil fuel costs avoided (expecting an oil price of $\$ 100$ per barrel in 2020, \$120/bl in 2030 and $\$ 200 / \mathrm{bl}$ in 2050) the economic benefit would increase to $€ 2090$ billion in 2050. Therefore, higher upfront investment needs will certainly pay off in the long run for European citizens. Besides, more than 6 million jobs would be created in the EU RES sector (EREC, 2010, pp. 3ff.).

Last but not least, there is an urgent need for strong and binding energy efficiency targets, not only for 2020 but also for 2030, 2040 and 2050, as these would strongly help to secure the increase of RES in overall energy consumption and bring down the total GHG emissions of Europe. The recasting of the Energy Service Directive planned for 2011-12 should be a good window of opportunity for finally establishing binding energy efficiency targets, the only pillar still missing in the EU's strongly interdependent energy and climate strategy, based on RES, GHG reductions and energy efficiency. 


\section{REFERENCES}

Bechberger, Mischa (2009), Erneuerbare Energien in Spanien, Stuttgart, Germany: ibidem.

Energy Research Centre of the Netherlands (2011), Renewable Energy Projections as Published in the National Renewable Energy Action Plans of the European Member States - Executive Summary, accessed 15 June 2011 at www.ecn.nl/docs/library/ report/2010/e10069_summary.pdf.

European Climate Foundation (2010), Roadmap 2050: A Practical Guide to a Prosperous, Low-Carbon Europe, accessed 15 June 2011 at www.roadmap2050.eu/ attachments/files/Volume1_fullreport_PressPack.pdf).

European Commission (2011), Impact Assessment of 'A Roadmap for Moving to a Competitive Low Carbon Economy in 2050, SEC(2011) 288 final, accessed 15 June at http://ec.europa.eu/clima/documentation/roadmap/docs/sec_2011_288_en.pdf.

European Photovoltaic Industry Association (2010), 'Market outlook 2010-2015', Brussels.

EPIA and Greenpeace (2011), 'Solar Generation 6 - solar photovoltaic electricity empowering the world - 2011', accessed 10 June at www.greenpeace.org/ international/Global/international/publications/climate/2011/Final\%20SolarGenera tion\%20VI\%20full\%20report\%20lr.pdf.

European Renewable Energy Council (EREC) (2010), Re-thinking 2050: A 100\% Renewable Energy Vision for the European Union - Executive Summary, accessed 10 June 2011 at www.rethinking2050.eu/fileadmin/documents/Rethinking2050 ExecutiveSummary_final.pdf.

EREC (2011), Mapping Renewable Energy Pathways Towards 2020 - EU Roadmap, accessed 10 June at www.repap2020.eu/fileadmin/user_upload/Roadmaps/ERECroadmap-V4_final.pdf.

EREC and Greenpeace (2010), Energy (R)evolution - A Sustainable World Energy Outlook, accessed 10 June 2011 at www.energyblueprint.info/fileadmin/media/ documents/2010/0910_gpi_E_R_full_report_10_lr.pdf.

European Wind Energy Association (2011), Wind in Power - 2010 European Statistics, accessed 10 June at www.ewea.org/fileadmin/ewea_documents/documents/ statistics/EWEA_Annual_Statistics_2010.pdf.

Eurostat (2011), Energy, Transport and Environment Indicators - 2010 Edition, accessed 10 June at http://epp.eurostat.ec.europa.eu/cache/ITY_OFFPUB/KS-DK10-001/EN/KS-DK-10-001-EN.PDF.

Fouquet, D. (2011), Overview on the National Renewable Energy Actions Plans of the EU Member States with Focus on PV, accessed 10 June at www.repap2020.eu/ fileadmin/user_upload/Roadmaps/Recommendations_BBH.pdf.

Global Wind Energy Council (2011), Global Wind Report - Annual Market Update 2010, accessed 15 June at http://www.gwec.net/fileadmin/documents/Publications/ Global_Wind_2007_report/GWEC\%20Global\%20Wind\%20Report\%202010\%201 ow\%20res.pdf.

Greenpeace (2011), Fukushima 1 (Daiichi) Radiation Briefing, accessed 12 June at http://www.greenpeace.org/international/en/campaigns/nuclear/safety/accidents/ Fukushima-nuclear-disaster/Fukushima-radiation-briefing/.

Jacobson, M.Z. and M.A. Delucchi (2009), A Path to Sustainable Energy by 2030, accessed 1 July at www.solaripedia.com/files/399.pdf.

Manager Magazin (2011), Brent Oil Spot, accessed 18 June 2010 at http://boersen.manager-magazin.de/spo_mmo/kurse_einzelkurs_uebersicht.htm?s= BRENTDAT.RSM\&b=400\&l=276\&n=OIL\%20in\%20USD. 
Renewable Energy Policy Network for the 21st Century (2010), Global Trends in Green Energy 2009: New Power Capacity from Renewable Sources Tops Fossil Fuels Again in US, Europe, accessed 1 June 1011 at www.ren21.net/Portals/97/ documents/Media\%20Resources/REN21_GSR_2010_Press_Release.pdf.

Ragwitz, M. et al. (2011), Assessment of National Renewable Energy Action Plans, accessed 1 July at www.repap2020.eu/fileadmin/user_upload/Roadmaps/ Assessment_of_NREAPs_REPAP_report_-_interim_status_.pdf.

Scheer, H. (2010), 'Global reden, national bremsen', Le Monde Diplomatique, 12 February 2010, accessed 10 March at www.eurosolar.de/de/index.php?option= com_content\&task=view\&id=1297\&Itemid=340. 